\title{
Nanonized black soybean enhances immune response in senescence-accelerated mice
}

\author{
Yin-Ching Chan ${ }^{1,6}$ \\ Chia-Chuan Wu ${ }^{1,6}$ \\ Kung-Chi Chan' \\ Yo-Giao Lin' \\ Jiunn-Wang Liao ${ }^{3}$ \\ Ming-Fu Wang' \\ Yung-Ho Chang' \\ Kee-Ching Jeng ${ }^{2,4,5}$
}

'Departments of Food and Nutrition and ${ }^{2}$ Applied Mathematics, Providence University, Taichung; ${ }^{3}$ Graduate Institutes of Veterinary Pathology and ${ }^{4}$ Medical Technology, National Chung Hsing University, Taichung, Taiwan; ${ }^{5}$ Department of Education and Research, Taichung Veterans General Hospital, Taichung, Taiwan; ${ }^{6}$ These authors have contributed equally to this work
Correspondence: Kee-Ching Jeng Department of Education and Research, Taichung Veterans General Hospital, Taichung 40705, Taiwan

Tel +88 6423592525 Ext. 4038

Fax +886423592705

Email kcjengmr@vghtc.gov.tw

\begin{abstract}
Soy isoflavones may have applications in cancer prevention and anti-inflammation, therefore this study was conducted to investigate the effect of dietary supplementation with black soybean on the immune response in the senescence-accelerated-prone mice (SAMP8) and -resistant mice (SAMPR1, as controls). The mechanism of isoflavones was also investigated. Six-month-old male SAMP8 and SAMR1 mice were divided into the control groups and experimental groups supplemented with nanonized (Nano-soy) or microparticled (Micro-soy) black soybeans ( $\mathrm{n}=8$ /group), respectively for 12 weeks. Human peripheral blood mononuclear cells (PBMC) and murine splenocytes were stimulated with mitogens and cytokines were determined by reverse transcriptase-polymerase chain reaction and/or ELISA. The results showed that body weight, food intake, and relative weights of organs did not differ among the SAMP8 control and experimental groups. Isoflavone (daidzin and genistin) intake was higher in the Nano-soy group than the Micro-soy group. The lymphoproliferation and production of interleukin-2 (IL-2) and interferon-gamma (IFN- $\gamma$ ) in the Nano-soy group had a significantly higher $(\mathrm{P}<0.05)$ than those in the control and Micro-soy groups. The Nano-soy supplemented mice reached these cytokine levels similar to SAMR1 mice. This result was consistent with the in vitro data that daidzein (a metabolite of daidzin), at a concentration of $10 \mu \mathrm{M}$, increased IL-2, IL-4, and IFN- $\gamma$ production from phytohemagglutinin-stimulated PBMC $(\mathrm{P}<0.05)$. However at higher concentrations $(>50 \mu \mathrm{M})$, daidzein only reduced IL-10 and IFN- $\gamma$ levels, whereas genistein reduced levels of the IL-2, IL-4, IL-10, IFN- $\gamma$ mRNA and protein and these results suggest that the Nano-soy supplementation improved immune response in SAMP8 mice which may be attributable to higher daidzin content in the black soybean preparation.
\end{abstract}

Keywords: nanonized black soybean, cytokines, senescence accelerated mice, splenocytes, peripheral blood mononuclear cells

\section{Introduction}

Changes in the immune function during aging lead to a higher rate of susceptibility to infectious disease and cancer in the elderly. ${ }^{1}$ In murine tuberculosis, T-helper 1 (Th1) cell immunity was impaired in old mice as compared with young mice. ${ }^{2}$ Aged C57BL/6 mice have impaired survival against fungal infection as compared with young mice. The antigen-induced tumor necrosis factor- $\alpha($ TNF- $\alpha)$ and interferon- $\gamma($ IFN- $\gamma)$ production by splenocytes is also diminished in old mice and correlates with a diminished frequency of IFN- $\gamma$-producing T cells. ${ }^{3}$ Similarly, T cells function is restricted in aged mice after viral infection. ${ }^{4}$ Senescence-accelerated-prone mice (SAMP8) mice have a short life span accompanied by normal growth as compared to SAMR1 mice that have a normal aging process. ${ }^{5}$ As early as two months after birth, SAMP8 mice show markedly lower activity for the immune indices such as natural killer (NK) cell activity, in vitro anti-sheep red blood cells antibody responses, cell proliferation, and IL-2-production to concanavalin A (Con A) stimulation than their normal counterparts, SAMR1 mice. ${ }^{6}$ A study showed that a diet supplemented with nucleoside-nucleotide mixture enhance the immune response in protein-deprived SAMP8 mice. $^{7}$ Similarly, dietary supplementation with 
cereals rich in polyphenolic compounds enhanced immune responses, such as IL-2 release, phagocytosis, and NK cell activity in prematurely aging mice. ${ }^{8}$ These dietary effect may be similar to the reversal of age-associated decline in effective immune synapse formation of $\mathrm{CD}^{+} \mathrm{T}$ cells by vitamin E supplementation. ${ }^{9}$

Soybean and soy products, which contain abundant isoflavones and soy protein, have many health benefits. Soy foods reduce the risk of atherosclerotic cardiovascular disease and improved the endothelial function. ${ }^{10-12}$ Soy protein inhibits the low-density lipoprotein (LDL) oxidation and lipid peroxidation. ${ }^{13,14}$ Moreover, the extract from black soybean has a longer LDL oxidation lag time than that from yellow soybean because of the high total polyphenols contents in its seed coat. ${ }^{13}$ The brown soybean seed coat was shown to have a high radical-scavenging activity by highly polymerized proanthocyanidins component. ${ }^{15}$ Another study showed that a diet enriched in soybean isoflavones and green tea enhances the immune function of ovariectomized mice in NK activity and lymphoproliferation compared with control mice. ${ }^{16}$ It has been known that the particle size of a chemical compound affects its physical, chemical, and biological properties. ${ }^{17}$ Nanonized selenium particles have better scavenging effects on the free radicals and protective effects against the oxidation of DNA. ${ }^{18}$ Similarly, nanonized red mold rice diet has been shown to have a significantly greater lipid lowering effect in hypolipidemic hamsters than in those with crude red mold rice. ${ }^{19}$ However, the biological effect between nanonized and microparticled soybeans is not clear. Therefore, our aim in this study was to investigate the immunologic effect of nanonized and microparticled black soybean diets in SAMP8 mice. Previously, a flavonoid, quercetin was reported to regulate cytokine gene expression by normal peripheral blood mononuclear cells (PBMCs). ${ }^{20}$ Other isoflavones from soybean might have similar effects and provide clues for the mechanism of soybean supplementation. We thus tested whether genistein and daidzein from soybean metabolites could regulate cytokine profile from human PBMCs.

\section{Materials and methods Chemicals}

Phytohemagglutinin (PHA), concanavalin A (Con A), lipopolysaccharide (LPS, Escherichia coli 0111:B4), 3-(4,5-dimethylthiazol-2-yl)-2,5-diphenyltetrazolium bromide (MTT) were obtained from Sigma Chemical (St. Louis, MO, USA). Cell culture ingredients were purchased from Life Technologies (Grand Island, NY, USA).
Fetal bovine serum (FBS) was obtained from Biological Industries (Kibbutz Beit Haemek, Israel). Murine IFN- $\gamma$, IL-2, IL-4, IL-5, and IL-10 ELISA kits were purchased from RayBiotech (Norcross, Ga, USA) and human IFN- $\gamma$, IL-2, IL-4, and IL-10 ELISA kits were obtained from R\&D (Minneapolis, MN, USA).

\section{Preparation and analysis of black soybean}

Black soybeans (black soybean, Tainan 3) were purchased from a local market in Taichung, Taiwan, and then ground to nanoparticles or microparticles by Taimao Co. (Taichung, Taiwan). The morphological characterization of nanonized black soybean after grinding was measured by scanning electron microscope (SEM) (JEOL JSM-6700F, Japan). The diameter of the nanonized black soybean samples was determined by small-scale powder disperser and a scanning mobility particle sizer spectrometer (TSI Incorp., Shoreview, MN, USA) under 5 liters per minute $(1 \mathrm{pm})$ air flow, while the aerosol sample flow rate and sheath flow rate were set at $0.3 \mathrm{lpm}$ and $3 \mathrm{lpm}$, respectively. The diameter of microparticled black soybean was also determined by using a dynamic laser-light scatteringbased particle size analyzer (Mastersizer Micro, Malvern Instruments, Malvern, UK) with 15\%-16\% for obscuration and $2520 \mathrm{rpm}$ for paddle speed. The diameter of nanonized and microparticled black soybean was 112 and 32,770 nm, respectively. For nanonized soybean, the percentages of particle size among less than $100 \mathrm{~nm}, 100-200 \mathrm{~nm}$, and 200-300 nm were $51.59 \%, 41.74 \%$, and 5.59\%, respectively. The compositions of nanonized and microparticled black soybean were analyzed in triplicate according to the published method. ${ }^{21}$

\section{Animals and diets}

Six-month-old senescence-accelerated-prone (SAMP8) and senescence-accelerated-resistant (SAMR1) mice were used in this experiment. The animals were kept in a conventional animal facility and housed in air-conditioned units $\left(22 \pm 2{ }^{\circ} \mathrm{C}, 65 \% \pm 5 \%\right.$ relative humidity) on a $12 \mathrm{~h}$ light/dark cycle. Animals were divided into control, nanonized black soybean and microparticled black soybean diet groups ( $n=8 /$ group), and allowed free access to the diets for 12 weeks. In both control groups, SAMP8 and SAMR1 mice were supplied with a standard purified casein diet according to the composition of AIN 93M diet. For the nanonized and microparticled black soybean diet groups, part of casein was replaced by black soybean with a final concentration of $10 \%$ of the whole diet. The food intake of the mice in each cage was recorded daily. The mice were 
weighed weekly. The study protocol was approved by the animal research ethics committee at Providence University, Shalu, Taiwan.

\section{Proliferation and cytokine production}

In order to examine the cell proliferation and cytokine production, we quickly dissected the spleens of mice and then used a tissue grinder to prepare splenocytes. The cells were prepared with RBC removal and resuspended in the RPMI-1640 medium supplemented with 10\% FBS, $100 \mathrm{U} / \mathrm{ml}$ penicillin and $100 \mu \mathrm{g} / \mathrm{ml}$ streptomycin. Splenocytes $\left(1 \times 10^{6}\right.$ cells $\left./ \mathrm{ml}\right)$ were cultured in 96-well microplate with the above complete medium and stimulated with LPS $(1 \mu \mathrm{g} / \mathrm{ml})$ or Con $\mathrm{A}(5 \mu \mathrm{g} / \mathrm{ml})$ at $37^{\circ} \mathrm{C}$ in a humidified incubator under $5 \% \mathrm{CO}_{2}$ for $48 \mathrm{~h}$. Culture supernatants were collected for cytokine assay. In the cell proliferation assay, splenocytes were cultured with Con A or LPS for 72 h. Proliferation was measured by production of blue formazan product from a colorless substrate, MTT. MTT was dissolved in DMSO and prepared as $5 \mathrm{mg} / \mathrm{ml}$ in PBS. The MTT assay was performed to detect the presence of mitochondrial hydrolases, which exist only in the living cells. Fifty $\mu$ l of MTT solution was added in each well and incubated for $4 \mathrm{~h}$. The absorbance was measured at $540 \mathrm{~nm}$ using a microplate reader (spectraMAX 340, Molecular Devices, Sunnyvale, CA). For cytokine production, culture supernatants were harvested and stored at $-70{ }^{\circ} \mathrm{C}$ until assay.

\section{Preparation of PBMCs and cell culture}

Blood samples were obtained from Taichung Blood Center (Taichung, Taiwan) by eight male healthy donors (age 25-46). Human PBMC were then purified by Ficoll-paque gradient centrifugation. The cells were prepared in RPMI-1640 medium supplemented with 10\% FBS, $100 \mathrm{U} / \mathrm{ml}$ penicillin and $100 \mu \mathrm{g} / \mathrm{ml}$ streptomycin. PBMCs at $2 \times 10^{6}$ cells $/ \mathrm{ml}$ were cultured in the complete medium and stimulated with PHA $(2.5 \mu \mathrm{g} / \mathrm{ml})$ with or without various concentrations of isoflavones at $37^{\circ} \mathrm{C}$ in a humidified incubator under $5 \% \mathrm{CO}_{2}$ for $8 \mathrm{~h}$ or $24 \mathrm{~h}$. Genistein and daidzein were dissolved in DMSO. Final DMSO concentration in the cell culture was less than $0.1 \%$. Cells were prepared for RT-PCR and culture supernatants were stored at $-70{ }^{\circ} \mathrm{C}$ until assay.

\section{Cell viability}

In order to examine the relationship between the cell viability and cytokine production from treated and non-treated cells, PBMCs at $2 \times 10^{6}$ cells $/ \mathrm{ml}$ were stimulated with
PHA $(2.5 \mu \mathrm{g} / \mathrm{ml})$ with or without various concentrations of daidzein or genistein at $37^{\circ} \mathrm{C}$ for $24 \mathrm{~h}$. The MTT assay was used to determine the cell viability.

\section{Isolation of RNA and RT-PCR for cytokine mRNA}

After treatment of cells for $8 \mathrm{~h}$, total cellular RNA was extracted with a cold RNA extraction solution (Ultraspec RNA; Biotex Inc., Houston, TX). The RT-PCR assays were performed with a Titan ${ }^{\mathrm{TM}}$ One Tube RT-PCR System kit (Boehringer, Mannheim, Germany). Briefly, $1 \mu \mathrm{g}$ of total RNA from each sample was added to $50 \mu \mathrm{l}$ of a reaction mixture containing $0.2 \mathrm{mM}$ dNTP, $0.4 \mu \mathrm{M}$ each of sense and antisense specific primers, $5 \mathrm{mM}$ DTT, $5 \mathrm{U}$ RNase inhibitor, $1 \mu \mathrm{l}$ of AMV reverse transcriptase (Chimerx, Madison, Wis, USA) and Expand ${ }^{\mathrm{TM}}$ High Fidelity enzyme mix (Roche, Taiwan). Taq DNA polymerase (5 U/ $\mu 1$, Viogene, Sunnyvale, CA, USA) was then added to the tube. The primer sequences and PCR parameters are listed in Table 1. The $\beta$-actin (540-bp fragment) served as a control for the RNA isolation and reverse-transcription. RT-PCR was conducted in a Perkin Elmer Cetus thermocycler (Norwalk, CT, USA) with 28 denaturation, annealing, and extension cycles. The PCR product was electrophoresed in a $2.5 \%$ agarose gel and verified by predicted size. Sequence analysis of each cDNA fragment was compared and verified with gene bank data. Quantification of the band density was performed by densitometric analysis (Digital Image Analysis System, PDI, Huntington Station, NY), and calculated as the optical density $\times$ area of band. Relative ratio of each cytokine/ $\beta$-actin was calculated and compared.

\section{Enzyme-linked Immunosorbent Assay (ELISA)}

Cytokine production from cultural supernatant of Con A-stimulated splenocytes or PHA-stimulated PBMC was assayed by ELISA method. Human and murine IFN- $\gamma$, IL-2, IL-4, IL-5, and IL-10 were measured by respective cytokine ELISA kits. The absorbance at $450 \mathrm{~nm}$ was determined using a microplate reader (spectraMAX 340).

\section{Statistical analyses}

All data are expressed as mean \pm standard error of the mean and analyzed using the SPSS 10.0 software (SPSS Inc., Chicago, IL, USA). Data were evaluated by multifactorial analysis or one-way ANOVA. The least significant difference test was used for pair-wise comparisons when the F-test was 
Table I The sequence of primers and PCR condition

\begin{tabular}{|c|c|c|c|}
\hline Gene & Primers & Parameters & Mol. size \\
\hline \multirow[t]{3}{*}{$\mathrm{IL}-2$} & 5' AACTCC TGT CTT GCA TTG CA & $94^{\circ} \mathrm{C}, \mathrm{I} \min$ & 441 \\
\hline & 3' GTG TTG AGA TGA TGC TTT GAC & $53^{\circ} \mathrm{C}, 1 \mathrm{~min}$ & \\
\hline & & $72^{\circ} \mathrm{C}, \mathrm{I} \min$ & \\
\hline \multirow[t]{3}{*}{ IL-4 } & 5' CAA CTT TGT CCA CGG ACA C & $96^{\circ} \mathrm{C}, 1 \mathrm{~min}$ & 345 \\
\hline & $3^{\prime}$ TCC AAC GTA CTCTGG TTG G & $60^{\circ} \mathrm{C}, 1 \mathrm{~min}$ & \\
\hline & & $73^{\circ} \mathrm{C}, 1.5 \mathrm{~m}$ & \\
\hline \multirow[t]{3}{*}{ IL-10 } & 5' ATGCCCCAAGCTGAGAACCAAGACCCA & $96^{\circ} \mathrm{C}, 30 \mathrm{~S}$ & 352 \\
\hline & 3' TCTCAAGGGGCTGGG CAGCTATC CCA & $60^{\circ} \mathrm{C}, 1 \mathrm{~min}$ & \\
\hline & & $73^{\circ} \mathrm{C}, 1.5 \mathrm{~min}$ & \\
\hline \multirow[t]{3}{*}{$\mathrm{IFN}-\gamma$} & 5' ATG GAG AGC CAA ATT GTC TCC & $96^{\circ} \mathrm{C}, 30 \mathrm{~S}$ & 300 \\
\hline & 3' TTA CTG GGA TGC TCT TCG ACC & $60^{\circ} \mathrm{C}, 1 \mathrm{~min}$ & \\
\hline & & $73^{\circ} \mathrm{C}, 1.5 \mathrm{~m}$ & \\
\hline \multirow[t]{3}{*}{$\beta$-actin } & 5' GCA AGA GAG GCA TCС TCA CC & $96^{\circ} \mathrm{C}, \mathrm{I} \min$ & 240 \\
\hline & 3' GCA CAG CCT GGA TAG CAA CG & $57^{\circ} \mathrm{C}, 1 \mathrm{~min}$ & \\
\hline & & $72^{\circ} \mathrm{C}, \mathrm{I} \min$ & \\
\hline
\end{tabular}

Abbreviations: IFN- $\gamma$, interferon-gamma; IL, interleukin; PCR, polymerase chain reaction.

significant. Differences were considered to be significant at $\mathrm{P}<0.05$ level.

\section{Results}

\section{Body weight, food intake and relative organ weights}

There was no difference in the accumulated body weights and food intake of six-month-old SAMP8 mice fed with different diets among the control, nanonized and microparticled black soybean diet groups $(\mathrm{P}>0.05$, Table 2$)$. The relative weights of heart, liver, spleen, lung and kidney did not differ among three groups (data not shown). These results indicated that the nanonized black soybean diet did not cause any alteration in the body weight, food intake, and organ weights of mice. However, isoflavone intake of mice fed with the nanonized black soybean diet was greater than that of mice fed with the microparticled black soybean diet as determined by HPLC method. Total isoflavones intake was 6.95 and $4.32(\mathrm{mg} / \mathrm{d})$; daidzins, 2.80 and $1.58(\mathrm{mg} / \mathrm{d})$; and genistins, 3.30 and $1.64(\mathrm{mg} / \mathrm{d})$, respectively for nanonized and microparticled black soybean diets.

\section{Lymphoproliferation}

After 12 weeks of supplementation with nanonized black soybean, the mitogen-induced proliferation of splenocytes from SAMP8 mice was significantly enhanced $(\mathrm{P}<0.05)$

Table 2 Body weight changes, food intake, and immune response of SAMRI and SAMP8 mice fed with different diets for I2 weeks

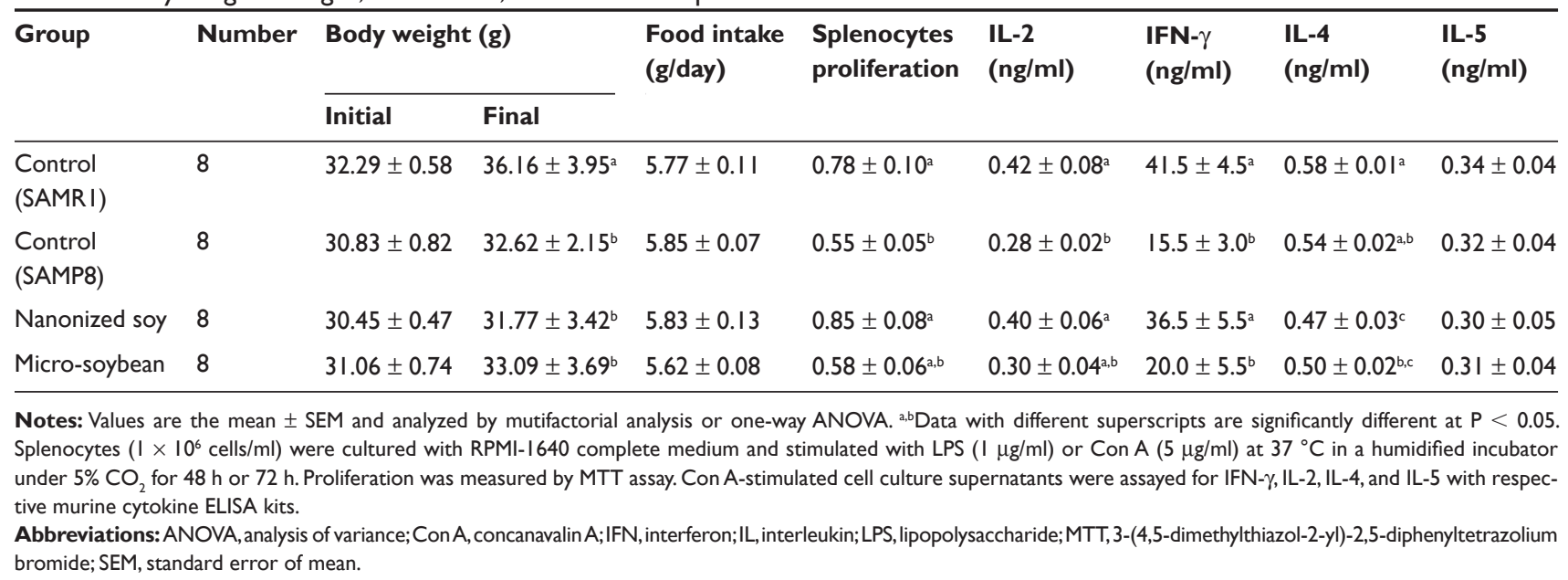


and reached to the control level of SAMR1 mice. However, supplementation with micropaticled black soybean in SAMP8 mice did not improve the proliferative responses of splenocytes as compared with control diet (Table 2).

\section{Cytokine production}

Production of IL-2 and IFN- $\gamma$ from SAMP8 mice was significantly lower than that from the control SAMR1 mice. Supplementation with nanonized black soybean significantly $(\mathrm{P}<0.05)$ restored the IL-2 and IFN- $\gamma$ production in SAMP8 mice and reached the levels of SAMR1 mice. However, microparticled black soybean supplementation in SAMP8 mice only slightly improved cytokine production $(\mathrm{P}>0.05)$. Nanonized black soybean supplementation in SAMP8 mice significantly reduced the IL-4 but not IL-5 production as compared with control diet $(\mathrm{P}<0.05)$.

\section{Mechanism of cytokine modulation}

Daidzein and genistein (metabolites of daidzin and genistin, respectively) were tested for their effects on cytokine production in human PBMCs. The result showed that daidzein, at a lower concentration $(10 \mu \mathrm{M})$, increased IL-2, IL-4, and IFN- $\gamma$ productions from PHA- and PHA plus vehicle (V, DMSO)-stimulated PBMCs $(\mathrm{P}<0.05)$. However at higher concentrations $(>50 \mu \mathrm{M})$, daidzein only reduced of IL-10 and IFN- $\gamma$ levels, whereas genistein reduced levels of IL-2, IL-4, IL-10, IFN- $\gamma$ mRNA and protein $(\mathrm{P}<0.05$, Figures 1-4). The effect was not associated with change of cell viability caused by daidzein and genistein treatment, because there was no difference in cell viability among treated groups and the medium control, PHA or PHA $+\mathrm{V}$ groups (data not shown).

\section{Discussion}

SAMP8 mice have a short life span accompanied by normal growth as compared with SAMR1 mice, which have a normal aging process. We found that supplementation with nanonized black soybean significantly enhanced the proliferation of splenocytes from SAMP8 mice and reached the levels of SAMR1 mice. This effect was correlated with enhanced IL-2 and IFN- $\gamma$ production and reduced IL-4 production.

It has been suggested that $\mathrm{T}$ cell compartment in late life may be more prone to immune deficiency or cytokinemediated dysregulation in response to new or previously encountered pathogens. ${ }^{1}$ The lack of an adequate amount of Th1 cytokines shortly after injury in the aged mice may parallel the increased incidence of sepsis and death that occurs in aged burn patients. ${ }^{22}$ Therefore, altered lymphocyte response

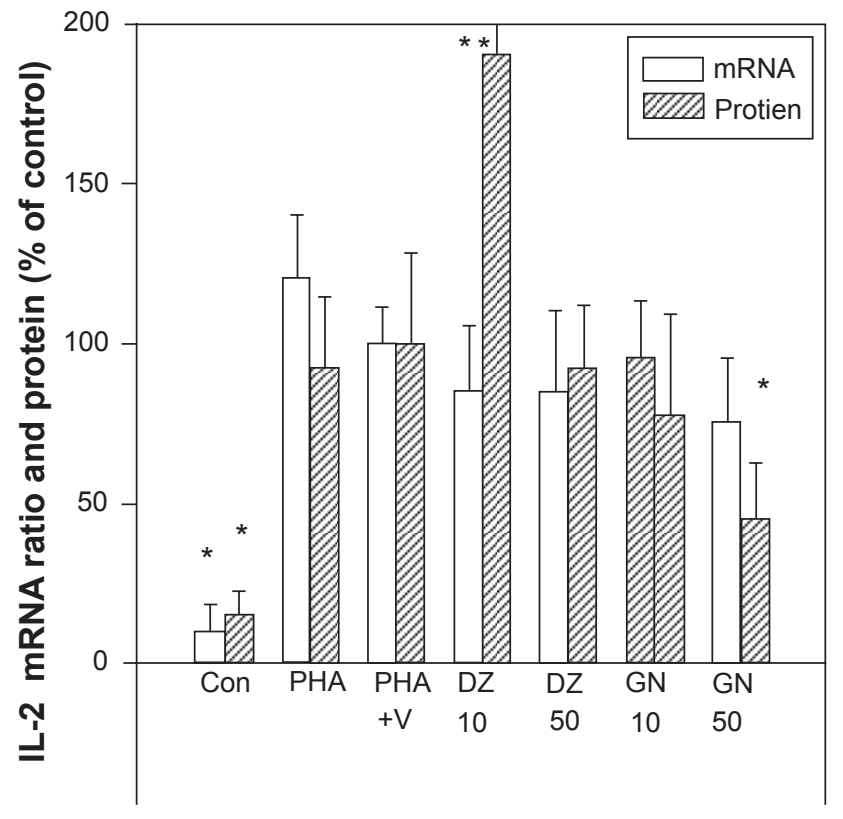

Figure I Effect of isoflavones on the levels of IL-2 mRNA and protein from PBMCs. PBMCs at $2 \times 10^{6}$ cells $/ \mathrm{ml}$ were cultured in the complete RPMI- 1640 medium and stimulated with PHA $(2.5 \mu \mathrm{g} / \mathrm{ml})$ with or without various concentrations of isoflavones at $37{ }^{\circ} \mathrm{C}$ in a humidified incubator under $5 \% \mathrm{CO}_{2}$ for $8 \mathrm{~h}$ or $24 \mathrm{~h}$. Genistein (GN) and daidzein (DZ) were dissolved in DMSO vehicle (V). DZ I0: daidzein $10 \mu \mathrm{M}$; GN 50: genistein $50 \mu \mathrm{M}$. The IL-2 gene was determined by RT-PCR and the IL-2 protein by ELISA assay.

Notes: ${ }^{*} \mathrm{P}<0.05$; $* * \mathrm{P}<0.01$ as compared with the PHA $+\mathrm{V}$ control level. Abbreviations: DMSO, dimethyl sulfoxide; IL, interleukin; mRNA, messenger ribonucleic acid; PBMCs, peripheral blood mononuclear cells; PHA, phytohemagglutinin.

observed in healthy aged individuals may be a contributing factor to increased mortality.

SAMP8 mice show markedly low NK activity, in vitro anti-SRBC antibody responses, cell proliferation, and IL-2 production, as early as two months after birth. Flow cytometry analysis shows that the number of $\mathrm{CD}^{+} \mathrm{T}$ cells in SAMP8 mice is smaller than that in SAMR1 mice. ${ }^{6}$ Our lymphoproliferation data on SAMP8 mice were in line with these reports. ${ }^{6,23}$ However, supplementation with nanonized black soybean for 12 weeks, significantly $(P<0.05)$ enhanced the proliferation, IL-2 and IFN- $\gamma$ production of splenocytes from SAMP8 mice. A study in which SAMP8 mice were given nucleoside-nucleotide mixture supplementation also showed enhanced lymphoproliferation and IL-2 and IFN- $\gamma$ productions in protein-deprived SAMP8 mice. $^{7}$

Our data on IL-4 and IL-5 production in male SAMP8 mice showed partial agreement with other report. ${ }^{23}$ They found that levels of IL-4 production were lower in SAMP8 than in AKR mice, although there was no difference in IL-5 production between two strains of mice. We found that IL-4 and IL-5 production was similar between SAMP8 and SAMR1 mice and nanonized black soybean supplementation significantly reduced the IL-4 but not IL-5 production. 


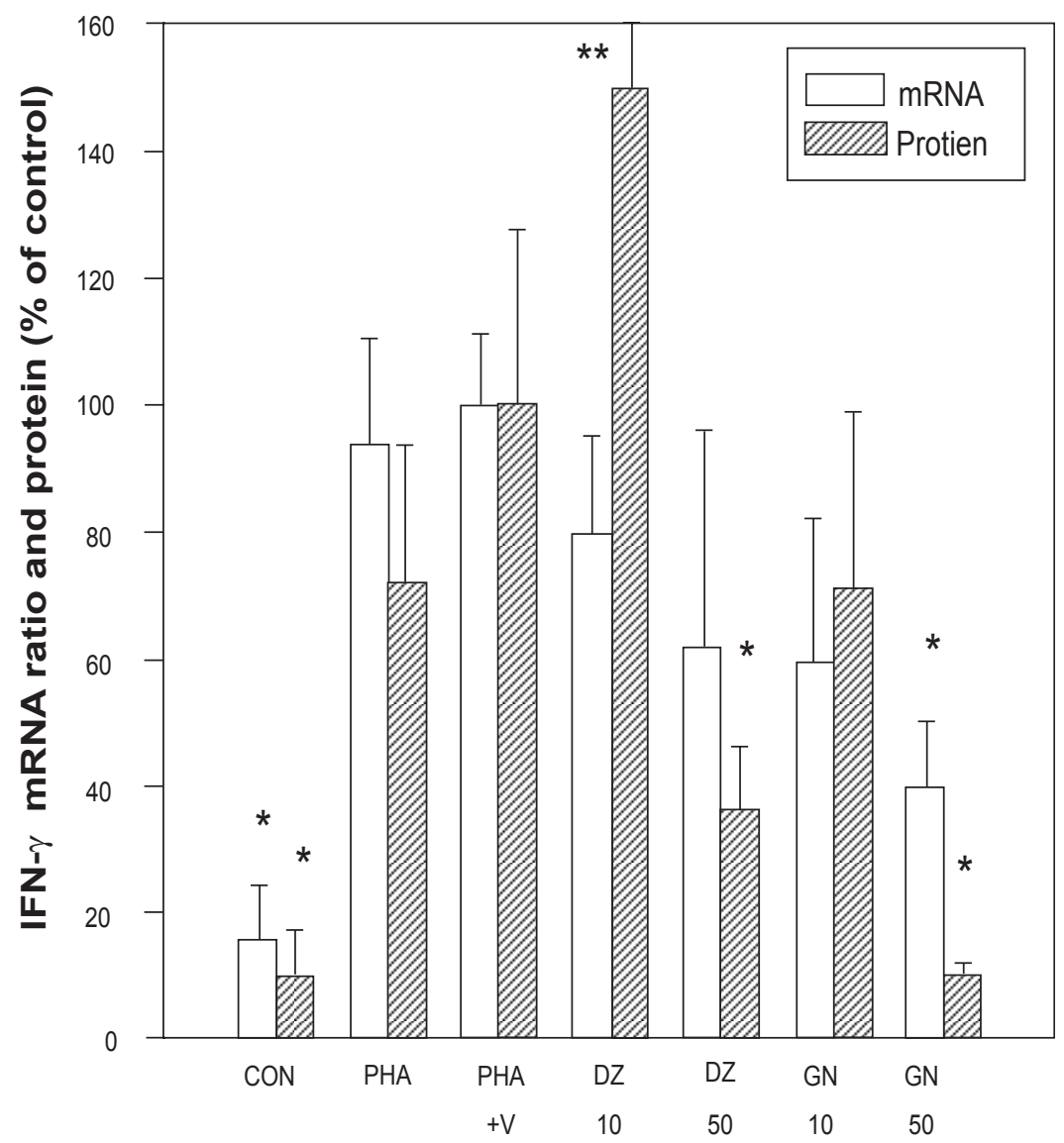

Figure 2 Effect of isoflavones on the levels of IFN- $\gamma$ mRNA and protein from PBMCs. PBMCs were stimulated with PHA with or without various concentrations of isoflavones for $8 \mathrm{~h}$ or $24 \mathrm{~h}$. The IFN- $\gamma$ mRNA was determined by RT-PCR and the IFN- $\gamma$ by ELISA assay.

Notes: $* \mathrm{P}<0.05$; **P $<0.01$ as compared with the PHA $+\mathrm{V}$ control level.

Abbreviations: IFN, interferon; mRNA, messenger ribonucleic acid;PBMCs, peripheral blood mononuclear cells; PHA, phytohemagglutinin; RT, reverse transcriptase-polymerase chain reaction.

Since an adequate amount of Th1 cytokines is critical to host defense in the aged animals, ${ }^{22}$ the supplementation with nanonized black soybean might provide a beneficial effect by favoring Th1 response in SAMP8 mice.

High soybean consumption leading to high exposure to soy isoflavones has been associated with a reduced risk of cancers. Two major soy isoflavones, daidzein and genistein, have been reported to have a potential protective effect against cancers. A study that investigated the modulating effects of daidzein in Swiss mice for seven day found that at high doses (20 and $40 \mathrm{mg} / \mathrm{kg}$ ), daidzein increased phagocytic response of peritoneal macrophages and thymus weight, in a dose-dependent manner. ${ }^{24}$ Our result using nanonized soybean supplementation and in vitro isoflavones treatment correlated well with a study which showed that daidzein, but not genistein, significantly potentiates proliferation and IL-2 and IL-3 production in a dose-dependent manner. ${ }^{25}$ Daidzein enhanced IL-2 and IFN- $\gamma$ production in PBMCs mainly through a post-transcription effect as the IL-2 and
IFN- $\gamma$ mRNA levels were not different from the levels of the PHA- and PHA-vehicle stimulated controls. This is important because that effect of aging on IL-2 production is reversible only in the presence of exogenous IL-2. ${ }^{26}$ The estimated isoflavone intake of mice fed with the nanonized black soybean diet was greater than that of mice fed with the microparticled black soybean diet: total isoflavones, 6.95 and $4.32(\mathrm{mg} / \mathrm{d})$; daidzins, 2.80 and $1.58(\mathrm{mg} / \mathrm{d})$; and genistins, 3.30 and $1.64(\mathrm{mg} / \mathrm{d})$, respectively. The estimated intake of daidzein was 0.29 and $0.11(\mathrm{mg} / \mathrm{d})$ and genistein, 0.28 and $0.11(\mathrm{mg} / \mathrm{d})$ respectively for nanonized and microparticled black soybean diet. Since more daidzins and its active metabolite, daidzein were available for mice receiving nanonized black soybean diet than that with microparticled black soybean diet, it correlated well with the Th1 enhancement effect by nanonized black soybean diet. It is possble that microparticled black soybean diet may achieve a similar immune enhancement effect with the same level of isoflavone content. 


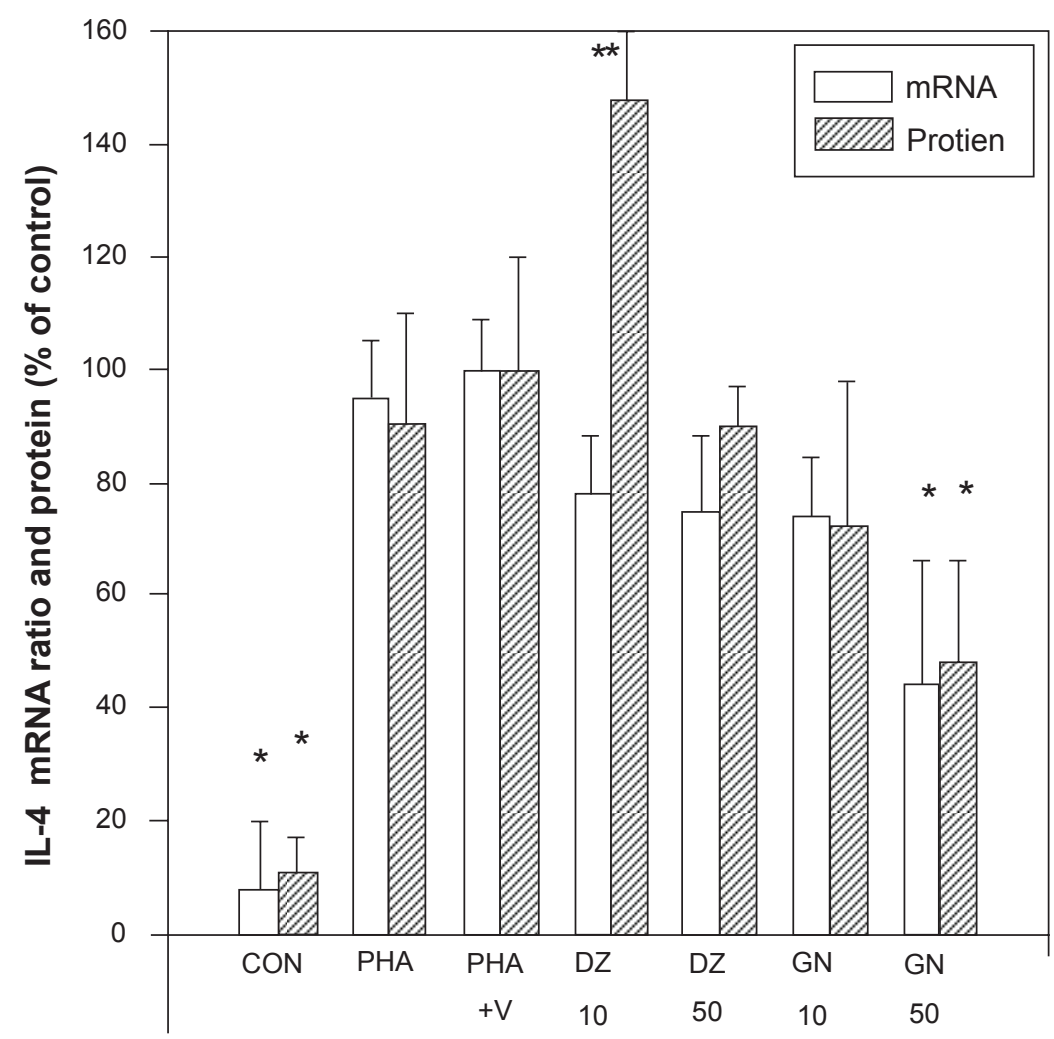

Figure 3 Effect of isoflavones on the levels of IL-4 mRNA and protein from PBMCs. The IL-4 mRNA was determined by RT-PCR and the IL-4 protein by ELISA assay. Notes: $* \mathrm{P}<0.05 ; * * \mathrm{P}<0.01$ as compared with the $\mathrm{PHA}+\mathrm{V}$ control level.

Abbreviations: IL, interleukin;mRNA, messenger ribonucleic acid; PBMCs, peripheral blood mononuclear cells; PHA, phytohemagglutinin; RT, reverse transcriptase-polymerase chain reaction.

Flavones can modulate the immune responses and the inflammatory reactions by controlling production of nitric oxide. ${ }^{27}$ Soy isoflavones, such as genistein, daidzein, and biochanin A, suppress nuclear factor- $\mathrm{KB}(\mathrm{NF}-\kappa \mathrm{B})$-driven IL-6 expression, independently of their estrogenic activity. This occurs via attenuation of mitogen-activated protein kinase (MEK) and extracellular signal-regulated kinase (ERK) activities, which further down-regulates NF- $\mathrm{KB}$ p65 and histone $\mathrm{H} 3$ phosphorylation. ${ }^{28}$ In one study, twelve postmenopausal women ingested $36-\mathrm{oz}$ of soymilk containing isoflavones daily for 16 weeks. ${ }^{29}$ The result shows that serum levels of TNF- $\alpha$ decreased by $25.1 \%$ as early as 2 weeks after soy consumption and by $66.7 \% 10$ weeks after soy consumption and recovered to the prediet levels 4 weeks after the termination of soy consumption. Similar decreases of up to 56.6 and $14.4 \%$ were found for serum IL- $1 \alpha$ and the mean percentage of blood monocytes during soy consumption, respectively, but not for IL-6. Genistein and daidzein $(1 \mathrm{mM})$ inhibits LPS-induced TNF- $\alpha$ production from PBMCs by up to $55.8 \%$.

Current theory holds that these late-life vulnerabilities arise, in part, through age-related changes in immune function, particularly in the $\mathrm{T}$ lymphocyte lineage and the causes of these alterations are multifactorial. The $\mathrm{T}$ cell compartment in late life may be more prone to immune deficiency or cytokinemediated dysregulation. ${ }^{1}$ Diet is one of the major exogenous factors modulating individual immunocompetence. Recently, nutrition research has focused on the role of foods or specific food components in enhancing immune system responsiveness to challenges and thereby improving health and reducing disease risks. ${ }^{30}$ Flavonoids are dietary antioxidants and exert significant anti-tumor, anti-allergic, anti-inflammatory and anti-viral effects. It is generally accepted that Th1-derived cytokines such as IL-2, IFN- $\gamma$, and IL-12 promote cellular immunity whereas Th2-derived cytokines such as IL-4, IL-5, IL-6 exert negative immunoregulatory effects on cellular immunity while upregulating humoral immunity. Quercetin treatment increased the phenotypic expression of IFN- $\gamma$ cells and decreased IL-4 positive cells based on FACS analysis, which corroborate with protein secretion and gene expression studies. ${ }^{20}$ In our study, IL-2, IL-4, and IFN- $\gamma$ production was enhanced by daidzein $(10 \mu \mathrm{M})$ but not genistein. However at higher concentrations $(>50 \mu \mathrm{M})$, daidzein reduced only IL-10 and IFN- $\gamma$ levels, whereas genistein reduced levels of 


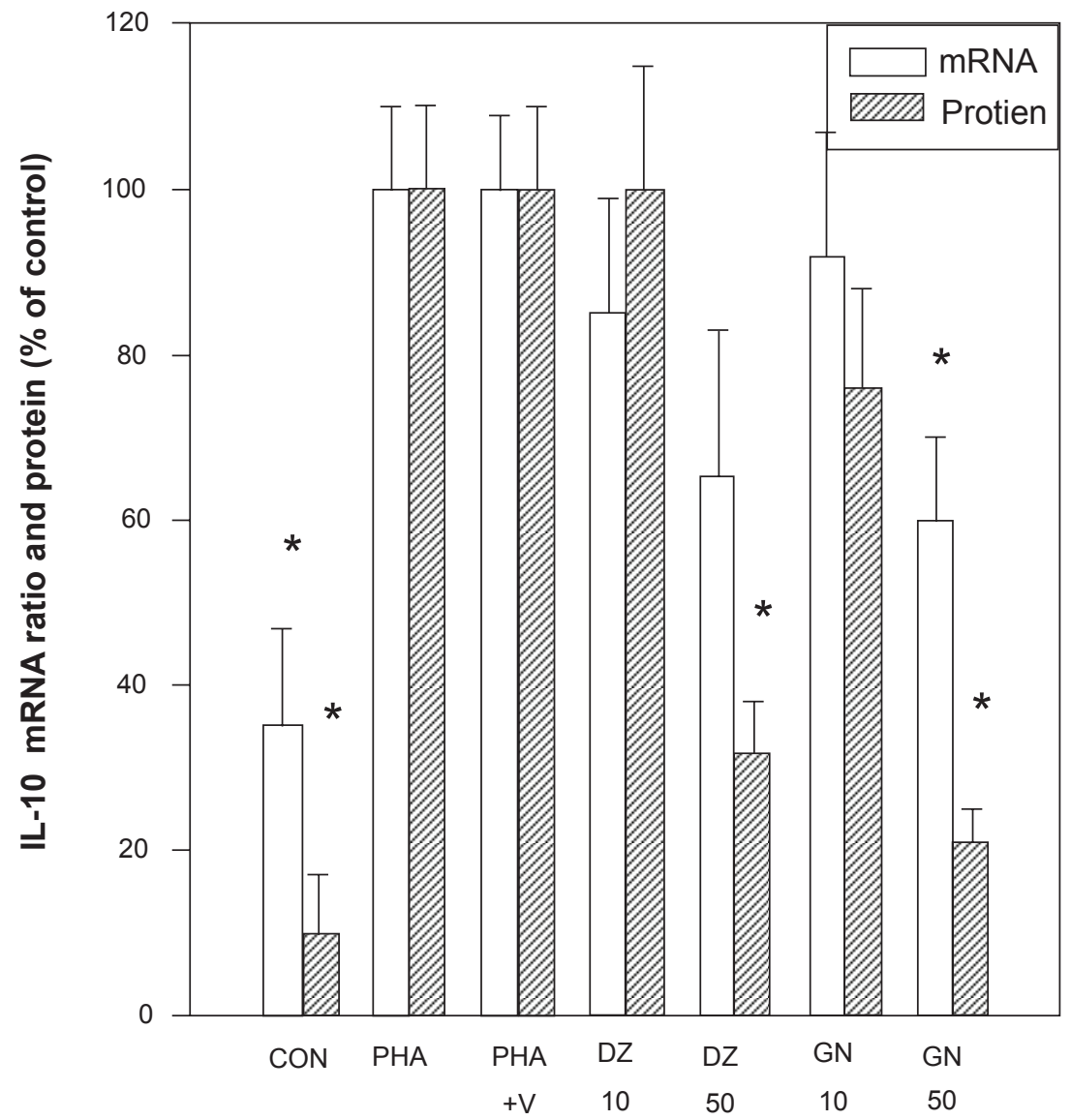

Figure 4 Effect of isoflavones on the levels of IL- I0 mRNA and protein from PBMC. The IL-I0 mRNA was determined by RT-PCR and the IL-I0 protein by ELISA assay. Notes: ${ }^{*} \mathrm{P}<0.05$ as compared with the $\mathrm{PHA}+\mathrm{V}$ control level.

Abbreviations: IL, interleukin; mRNA, messenger ribonucleic acid; PBMCs, peripheral blood mononuclear cells; RT, reverse transcriptase-polymerase chain reaction.

the IL-2, IL-4, IL-10, IFN- $\gamma$ mRNA, and protein. This effect is similar to its anti-inflammatory effect by NF- $\kappa$ B suppression. These results suggest that the beneficial immuno-enhancing effect of daidzein may be mediated through the induction of Th1-derived cytokine, IFN- $\gamma$ and IL-2. Our result with nanonized black soybean supplementation are in line with those of a study in which aged mice were treated with isoflavones for five weeks. ${ }^{16}$ These results suggest that an adequate treatment with isoflavones can be useful in slowing down the effects of the aging process through an improvement in the immune functions. Considering the public health consequences of decreased immune competence in old age, strategies for immune response modulation are needed to decrease the health burden for the elderly and improve their quality of life. ${ }^{31}$ Soybean and soy products, which contain abundant isoflavones and soy protein, have many health benefits. Our results confirm that the nanonized soybean diet contains more isoflavones and has a greater beneficial effect on the immune function than the microparticled soybean diet in senescenceaccelerated mice. However, due to the difficulty in breeding this genetic defect strain of mice, the study groups are small. It may need a larger number of animals to further confirm this beneficial effect in future.

Present results indicate that supplementation with nanonized black soybean can enhance lymphoproliferation and Th1 cytokine production in SAMP8 mice. We also showed that nanonized black soybean diet had more beneficial effect than microparticled diet, possibly because it provided more isoflavones. The mechanism of active components of nanonized black soybean on immunomodulation is partly related with daidzin but the precise mechanism requires further study.

\section{Acknowledgments}

The study was supported by the National Science Council, Taiwan (NSC-94-2622-B-126-001-CC3), Republic of China. Contributions: animal studies: YC Chan, YG Lin, JW Liao, MF Wang; Nanoparticle size measurement: YH Chang; PBMCs study: CC Wu, KC Chan; Exp. design: YC Chan, $\mathrm{KC}$ Jeng. The authors declare no conflicts of interest. 


\section{References}

1. Hobbs MV, Ernst DN. T cell differentiation and cytokine expression in late life. Dev Comp Immunol. 1997;21:461-470.

2. Vesosky B, Turner J. The influence of age on immunity to infection with Mycobacterium tuberculosis. Immunol Rev. 2005;205:229-243.

3. Murciano C, Villamon E, Yanez A, et al. Impaired immune response to Candida albicans in aged mice. J Med Microbiol. 2006; 55:1649-1656.

4. Yager EJ, Ahmed M, Lanzer K, et al. Age-associated decline in T cell repertoire diversity leads to holes in the repertoire and impaired immunity to influenza virus. $J$ Exp Med. 2008;205:711-723.

5. Takeda T, Hosokawa M, Higuchi K. Senescence-accelerated mouse (SAM): a novel murine model of accelerated senescence. J Am Geriatr Soc. 1991;39:911-919.

6. Abe Y, Yuasa M, Kajiwara Y, et al. Defects of immune cells in the senescence-accelerated mouse: a model for learning and memory deficits in the aged. Cell Immunol. 1994;157:59-69.

7. Ameho CK, Adjei AA, Yamauchi K, et al. Modulation of age-related changes in immune functions of protein-deficient senescence-accelerated mice by dietary nucleoside-nucleotide mixture supplementation. BrJ Nutr. 1997;77:795-804.

8. Alvarez P, Alvarado C, Puerto M, et al. Improvement of leukocyte functions in prematurely aging mice after five weeks of diet supplementation with polyphenol-rich cereals. Nutrition. 2006;22:913-921.

9. Marko MG, Ahmed T, Bunnell SC, et al. Age-associated decline in effective immune synapse formation of $\mathrm{CD}^{+} \mathrm{T}$ cells is reversed by vitamin E supplementation. J Immunol. 2007;178:1443-1449.

10. Hanson LN, Engelman HM, Alekel DL, et al. Effects of soy isoflavones and phytate on homocysteine, C-reactive protein, and iron status in postmenopausal women. Am J Clin Nutr. 2006;84:774-780.

11. Liu JR, Wang SY, Chen MJ, et al. Hypocholesterolaemic effects of milk-kefir and soyamilk-kefir in cholesterol-fed hamsters. Br J Nutr. 2006;95:939-946.

12. Cassidy A, Albertazzi P, Lise-Nielsen I, et al. Critical review of health effects of soyabean phyto-oestrogens in post-menopausal women. Proc Nutr Soc. 2006;65:76-92.

13. Takahashi R, Ohmori R, Kiyose C, et al. Antioxidant activities of black and yellow soybeans against low density lipoprotein oxidation. J Agric Food Chem. 2005;53:4578-4582.

14. Pereira IR, Faludi AA, Aldrighi JM, et al. Effects of soy germ isoflavones and hormone therapy on nitric oxide derivatives, low-density lipoprotein oxidation, and vascular reactivity in hypercholesterolemic postmenopausal women. Menopause. 2006;13:942-950.

15. Takahata Y, Ohnishi-Kameyama M, Furuta S, et al. Highly polymerized proanthocyanidins in brown soybean seed coat with a high radicalscavenging activity. J Agric Food Chem. 2001;49:5843-5847.
16. Baeza I, de Castro NM, Alvarado C, et al. Improvement of immune cell functions in aged mice treated for five weeks with soybean isoflavones. Ann N Y Acad Sci. 1992;1100:497-504.

17. Ball P, Garwin L. Science at the atomic scale. Nature. 1992;355:761-766.

18. Huang B, Zhang J, Hou J, et al. Free radical scavenging efficiency of Nano-Se in vitro. Free Radic Biol Med. 2003;35:805-813.

19. Yu CC. A study on safety evaluation and lipid metabolism regulation in hamster given dietary supplement of nanoparticulated red mold rice. Taipei, Taiwan: Master's thesis, Institute of Microbiology and Biochemistry, National Taiwan University; 2006.

20. Nair MP, Kandaswami C, Mahajan S, et al. The flavonoid, quercetin, differentially regulates Th-1 (IFN- $\gamma$ ) and Th-2 (IL-4) cytokine gene expression by normal peripheral blood mononuclear cells. Biochim Biophys Acta. 2002;1593:29-36.

21. Delmonte P, Rader JI. Analysis of isoflavones in foods and dietary supplements. J AOAC Int. 2006;89:1138-1146.

22. Plackett TP, Schilling EM, Faunce DE, et al. Aging enhances lymphocyte cytokine defects after injury. FASEB J. 2003;17:688-689.

23. Aoki K, Asano K, Okamoto K, et al. Age-related changes in ConAinduced cytokine production by splenocytes from senescence accelerated mice SAMP8. Immunol Lett. 1995;46:169-175.

24. Vanden-Berghe W, Dijsselbloem N, Vermeulen L, et al. Attenuation of mitogen- and stress-activated protein kinase-1-driven nuclear factorkappaB gene expression by soy isoflavones does not require estrogenic activity. Cancer Res. 2006;66:4852-4862.

25. Zhang R, Li Y, Wang W. Enhancement of immune function in mice fed high doses of soy daizein. Nutr Cancer. 1997;29:24-28.

26. Wang W, Higuchi CM, Zhang R. Individual and combinatory effects of soy isoflavones on the in vitro potentiation of lymphocyte activation. Nutr Cancer. 1997;29:29-34.

27. Haynes L, Linton PJ, Eaton SM, et al. Interleukin 2, but not other common gamma chain-binding cytokines, can reverse the defect in generation of CD4 effector T cells from naive T cells of aged mice. J Exp Med. 1999;190:1013-1024.

28. Krol W, Czuba ZP, Threadgill MD, et al. Inhibition of nitric oxide (NO.) production in murine macrophages by flavones. Biochem Pharmacol. 1995;50:1031-1035.

29. Huang Y, Cao S, Nagamani M, et al. Decreased circulating levels of tumor necrosis factor-alpha in postmenopausal women during consumption of soy-containing isoflavones. J Clin Endocrinol Metab. 2005; 90:3956-3962.

30. Albers R, Antoine JM, Bourdet-Sicard R, et al. Markers to measure immunomodulation in human nutrition intervention studies. Br J Nutr. 2005;94:452-481.

31. Fulop T, Larbi A, Wikby A, et al. Dysregulation of T-cell function in the elderly: scientific basis and clinical implications. Drugs Aging. 2005; 22:589-603. 
